\title{
Basement Bar
}

\section{Amy O'Neill}

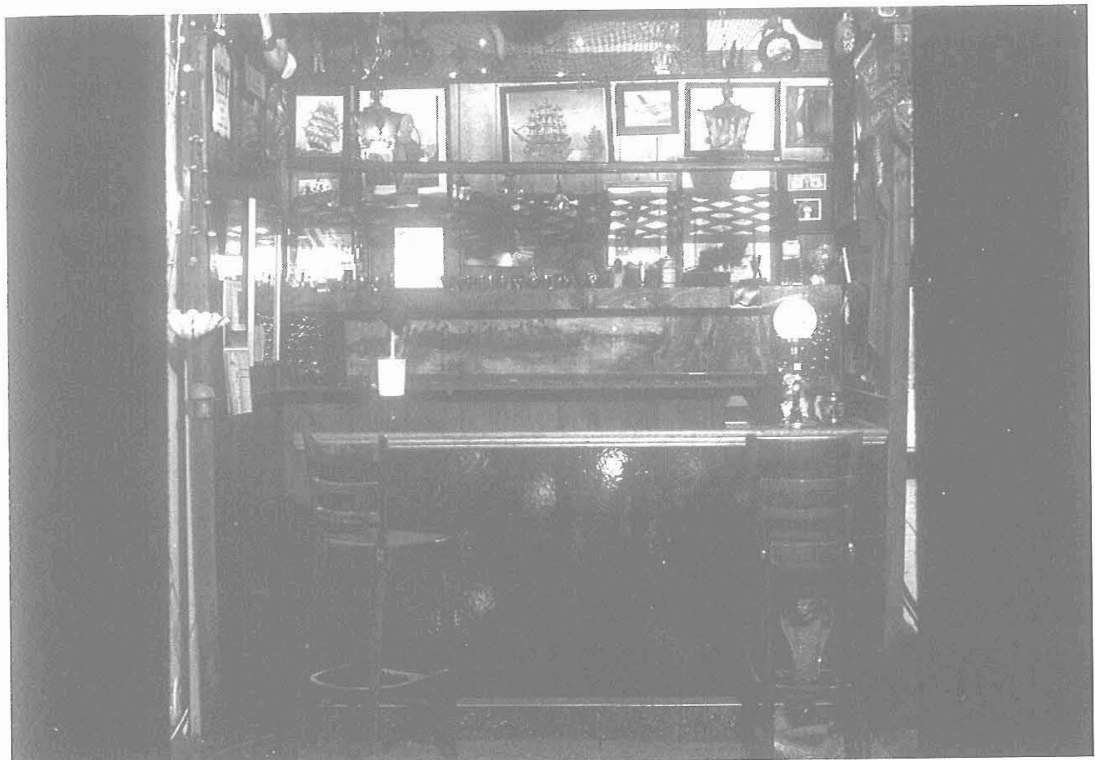

heirlooms, $8^{\prime} \times 4^{\prime} \times 8^{\prime}$ 